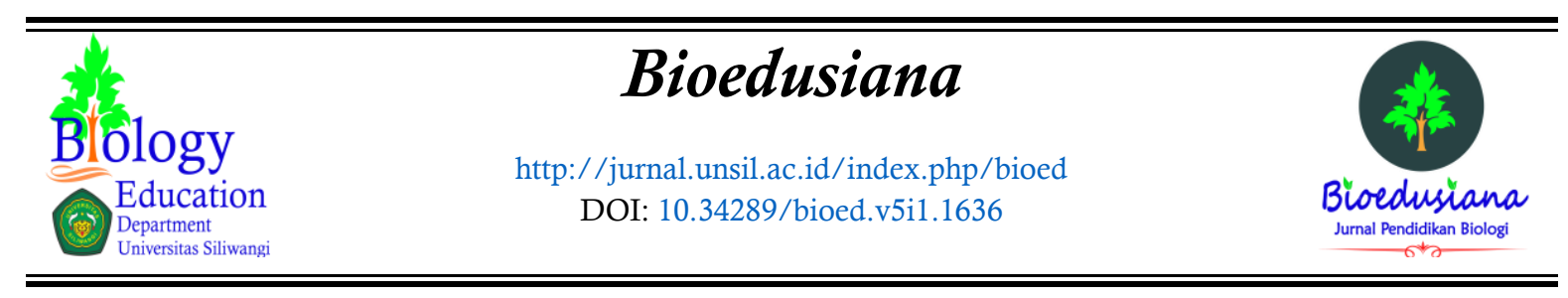

\title{
Eksplorasi Kemampuan Proses Inkuiri Mahasiswa Calon Guru IPA: Perspektif dari Gender dan Lama Studi
}

\section{Exploring Prospective Science Teacher Students' Inquiry Process Abilities: Perspective from Gender and Student's Years of Study}

\author{
Muhamad Arif Mahdiannur ${ }^{1 *}$, Hasan Subekti ${ }^{2}$, Aris Rudi Purnomo ${ }^{3}$ \\ 1,2,3) Program Studi Pendidikan Sains Universitas Negeri Surabaya, Surabaya, 60231
}

\begin{abstract}
Abstrak
Dalam beberapa tahun terakhir, pengembangan profesionalitas guru IPA mendapat perhatian yang besar, tetapi pengembangan profesionalitas mahasiswa calon guru IPA ditinjau dari kemampuan proses inkuirinya masih belum banyak yang menelitinya. Penelitian ini ditujukan untuk mengeksplorasi kemampuan proses inkuri mahasiswa calon guru IPA berdasarkan gender dan lama studi mahasiswa. Sebanyak 302 mahasiswa calon guru IPA turut berpartisipasi dalam riset ini. Mahasiswa tersebut mulai dari angkatan tahun I hingga tahun IV di salah satu Lembaga Pendidikan Tenaga Kependidikan (LPTK) di Jawa Timur. Data yang dikumpulkan dalam riset ini bersumber dari hasil tes kemampuan proses inkuiri yang sebelumnya telah disusun dan ditelaah oleh para ahli dengan metode screening. Hasil penelitian ini menunjukkan kecenderungan mahasiswa calon guru IPA laki-laki cenderung lebih unggul dalam membuat prediksi, penerapan metode statistik, dan membuat kesimpulan, sedangkan mahasiswa calon guru IPA perempuan cenderung unggul dalam identifikasi/merumuskan masalah dan mendesain eksperimen. Selain itu, hanya indikator kemampuan menerapkan metode statistik yang menunjukkan pola linier dengan lama masa studi mahasiswa calon guru IPA.
\end{abstract}

Kata kunci: Proses Inkuiri; Keterampilan Proses Sains; Keterampilan Berpikir; Pengembangan Profesional; Pendidikan Calon Guru

\begin{abstract}
In recent years, the professional development of science teachers has received great attention, but limited research on the professional development of prospective science teacher students in terms of the inquiry process abilities. This research purposed to explore the inquiry process abilities of prospective science teacher students based on gender and student's years of study. A total of 302 science teacher students participated in this research. The students started from the freshmen to the senior year in one of the Institute of Teacher Education (LPTK) in East Java. The data collected in this research was sourced from the results of the inquiry process abilities test, which had previously been compiled and reviewed by subject matter experts with screening methods. The results of this study indicate that the tendency of male prospective science teacher students tends to be superior in making predictions, applying statistical methods, and making conclusions. In contrast, female prospective science teacher students tend to excel in identifying/formulating problems and designing experiments. Besides, only the ability to apply statistical methods indicator that shows a linear pattern with the student's years of study.
\end{abstract}

Keywords: Inquiry Process; Science Process Skills; Thinking Skills; Professional Development; Teacher Candidate Education

Article History

Received: 30 April 2020 ;Accepted: 12 Mei 2020 ;Published: 30 Juni 2020

Corresponding Author*

Muhamad Arif Mahdiannur, Pendidikan Sains, Universitas Negeri Surabaya, 60231, Hp. +62 852-4721-5914

E-mail: muhamadmahdiannur@unesa.ac.id

(C) 2020 Bioedusiana. This is an open access article under the CC BY-SA 4.0 license

(https://creativecommons.org/licenses/by-sa/4.0/) 


\section{PENDAHULUAN}

Dalam lima tahun terakhir, pengembangan profesional guru IPA mendapat perhatian yang cukup besar di tingkat global (Bancroft \& Nyirenda, 2020; Kowalski et al., 2020; Nichol, Chow, \& Furtwengler, 2018; Wright, 2019). Mayoritas seluruh riset terkait pengembangan profesional guru IPA diarahkan untuk meningkatkan kualitas pengajaran, hasil belajar siswa, dan proses belajar-mengajar. Menyikapi perkembangan global tersebut, Kementerian Pendidikan dan Kebudayaan pada tahun 2019 juga telah membentuk Direktorat Pendidikan Profesi Guru dan Pembinaan Guru dan Tenaga Kependidikan di bawah Direktorat Jenderal Guru dan Tenaga Kependidikan.

Pendidikan IPA yang berkualitas harus dinikmati oleh setiap orang. Setiap anak harus disediakan fasilitas, kesempatan, peluang, sumber daya, dan guru IPA yang berkualitas (Gilbert, 2016; Zeyer, 2018). Pendidikan IPA urban saat ini masih kontinu untuk memprioritaskan pengetahuan konten sains dan fakta-fakta dibandingkan dengan relevansi dan/atau aplikasi (Marco-Bujosa, McNeill, \& Friedman, 2019). Selain itu, terdapat perbedaan yang fundamental antara frekuensi dan karakteristik pembelajaran berbasis inkuiri ditinjau dari hasil belajar IPA atau science achievement (Forbes, Neumann, \& Schiepe-Tiska, 2020).

Pendidikan IPA urban mengindikasikan seorang guru IPA urban memiliki tanggung jawab yang unik untuk mengembangkan misi pendidikan, baik di dalam maupun di luar kelas (MarcoBujosa et al., 2019). Realita yang dihadapi oleh para guru umumnya mereka menemukan kontradiksi antara kebutuhan di sekolah dan apa yang dipelajari selama perkuliahan (Rodriguez, 2015). Hal ini terjadi karena prioritas utama masih mengedepankan pengetahuan konten sains dan fakta-fakta, sehingga pengembangan kemampuan prosedural yang disertai penguasaan konsep substantif menjadi terabaikan dalam pendidikan mahasiswa calon guru IPA di LPTK.

Fokus pengembangan pendidikan IPA secara internasional menekankan pada literasi ilmiah peserta didik (Forbes et al., 2020). Peralihan pandangan dari hanya sekadar doing science menjadi belajar konsep-konsep IPA dan mengembangkan pemahaman konseptual menjadi kecenderungan dalam kurikulum IPA secara global. Peran guru IPA menjadi sangat penting dalam mendesain dan menyiapkan alat dan bahan investigasi ilmiah yang mendukung penguasaan konsep para peserta didik melalui kegiatan pembelajaran berbasis inkuiri.

Keterampilan ilmiah terdiri atas tiga bagian, yaitu: (1) keterampilan generik, (2) keterampilan proses sains, dan (3) keterampilan berpikir (Abrahams \& Reiss, 2015; Fadzil \& Saat, 2014; Molefe \& Stears, 2014). Pembagian keterampilan tersebut menyebabkan dapat saling tumpang-tindih indikator-indikator performa satu dengan yang lain dan biasanya disesuaikan dengan definisi yang ditetapkan karena banyaknya definisi dan ragam keterampilan dalam investigasi atau inkuiri sains (Abrahams \& Reiss, 2015). Agar menghindari tumpang-tindih tersebut dan mencoba untuk melakukan riset terkait keterampilan ilmiah yang belum banyak 
diteliti, kami memfokuskan pada kemampuan proses inkuiri mahasiswa calon guru IPA, yaitu identifikasi dan/atau merumuskan masalah, mendesain eksperimen, membuat hipotesis, membuat prediksi, penerapan metode statistik, dan membuat kesimpulan.

Selain itu, masih minim riset yang dilakukan berkaitan dengan eksplorasi kemampuan proses inkuiri mahasiswa calon guru IPA selama ini yang dikaitkan dengan pengembangan profesionalitas calon guru. Seyogyanya, pengembangan profesional guru IPA dimulai dari tingkat pendidikan sarjana calon guru IPA tersebut selama empat tahun di LPTK. Oleh karena itu, riset ini ditujukan untuk melihat sejauh mana kemampuan proses inkuiri mahasiswa calon guru ditinjau dari perspektif gender dan lama studi mahasiswa. Hasil penelitian ini diharapkan mampu memberikan gambaran mengenai bagaimana kemampuan guru IPA kontemporer dalam mendesain pembelajaran berbasis inkuiri berdasarkan kemampuan proses inkuiri yang dimilikinya.

\section{METODE}

Penelitian ini menggunakan pendekatan penelitian cross-sectional dalam bentuk studi kasus dengan one-shot survei atau tes (Farsakoğlu, Şahin, \& Karsli, 2012; Yakar, 2014). Proses penelitian ini diuraikan sebagai berikut:

\section{Subjek Penelitian/Grup Studi}

Penelitian ini melibatkan 302 orang mahasiswa calon guru IPA di salah satu LPTK di Jawa Timur yang terdiri atas 27 orang laki-laki dan 275 orang perempuan. Rentang usia subjek penelitian berkisar dari 17 tahun s.d. 22 tahun. Seluruh mahasiswa calon guru IPA telah memberikan persetujuan (consent) untuk diteliti dalam penelitian ini. Selain itu juga, prinsipprinsip anonimitas dan pseudonim serta kerahasiaan data tempat dan lokasi penelitian dilakukan sesuai kode etik penelitian.

\section{Pra-penelitian}

Kemampuan proses inkuiri yang akan dieksplorasi melalui tes haruslah memiliki kredibilitas untuk mengukur indikator-indikator kemampuan proses inkuiri calon guru IPA yang telah dirumuskan dalam riset ini. Indikator dan atribut kemampuan proses inkuiri dalam penelitian ini dirangkum di Tabel 1.

Setelah instrumen tes kemampuan proses inkuiri tersebut disusun, kemudian dengan metode screening yang melibatkan para ahli untuk menilai kesesuaian konstruksi dan isi instrumen dengan tujuan penelitian (Nieveen \& Folmer, 2013). Kesesuaian dan kecocokan penilaian dari para ahli dianalisis menggunakan Indeks Validitas $(V)$ dan reliabilitas diukur 
dengan koefisien $R$ dan $H$ (Aiken, 1985). Hasil penilaian dari para ahli menunjukkan bahwa instrumen kemampuan proses inkuiri telah sesuai dengan indikator dan atribut yang diinginkan.

Tabel 1. Indikator dan Atribut Kemampuan Proses Inkuiri

\begin{tabular}{ll}
\hline \multicolumn{1}{c}{ Indikator } & \multicolumn{1}{c}{ Atribut } \\
\hline Identifikasi/merumuskan masalah & $\begin{array}{l}\text { Mampu mengidentifikasi rumusan masalah yang bisa diuji } \\
\text { atau merumuskan masalah berdasarkan latar belakang } \\
\text { masalah } \\
\text { Mendesain eksperimen }\end{array}$ \\
& Mampu menentukan variabel manipulasi, variabel respons, \\
& bahan yang digunakan dalam eksperimen \\
& Mampu membuat dugaan berdasarkan variabel bebas dan \\
Membuat hipotesis & variabel respons dengan pola, "jika ..., maka ..." \\
& Mampu membuat prediksi atas hasil eksperimen yang akan \\
diperoleh berdasarkan konsep substantif & Mampu mengumpulkan data, menyajikan data, dan \\
Penerapan metode statistik & menganalisis data sesuai dengan metode statistik \\
& Mampu membuat kesimpulan yang menjawab rumusan \\
Membuat kesimpulan & masalah \\
\hline
\end{tabular}

\section{Pengumpulan Data}

Pengumpulan data dalam penelitian ini menggunakan teknik tes. Data yang dikumpulkan berupa kemampuan proses inkuiri mahasiswa calon guru IPA. Tes dilakukan di salah satu LPTK di Jawa Timur yang menyelenggarakan pendidikan guru IPA.

\section{Analisis Data}

Data hasil tes diinferensi sebagai kemampuan proses inkuiri mahasiswa calon guru. Data tersebut dikoding berdasarkan gender dan lama masa studi mahasiswa. Lama masa studi mahasiswa dibagai berdasarkan tahun studi. Pengelompokan lama studi mahasiswa disajikan pada Tabel 2. Setelah itu, kemudian dilakukan analisis dan dibandingkan dengan beragam teori dan hasil penelitian sebelumnya untuk menginterpretasi dan menjelaskan temuan dalam penelitian ini.

Tabel 2. Kluster Lama Studi Mahasiswa

\begin{tabular}{cc}
\hline Kluster & Semester \\
\hline Tahun I (freshmen) & I s.d. II \\
Tahun II (sophomore) & III s.d. IV \\
Tahun III (junior) & V s.d VI \\
Tahun IV (senior) & VII s.d. VIII \\
\hline
\end{tabular}




\section{HASIL DAN PEMBAHASAN}

Hasil kemampuan proses inkuiri mahasiswa calon guru IPA berdasarkan gender dan lama studi, disajikan dalam Gambar 1 dan Gambar 2.

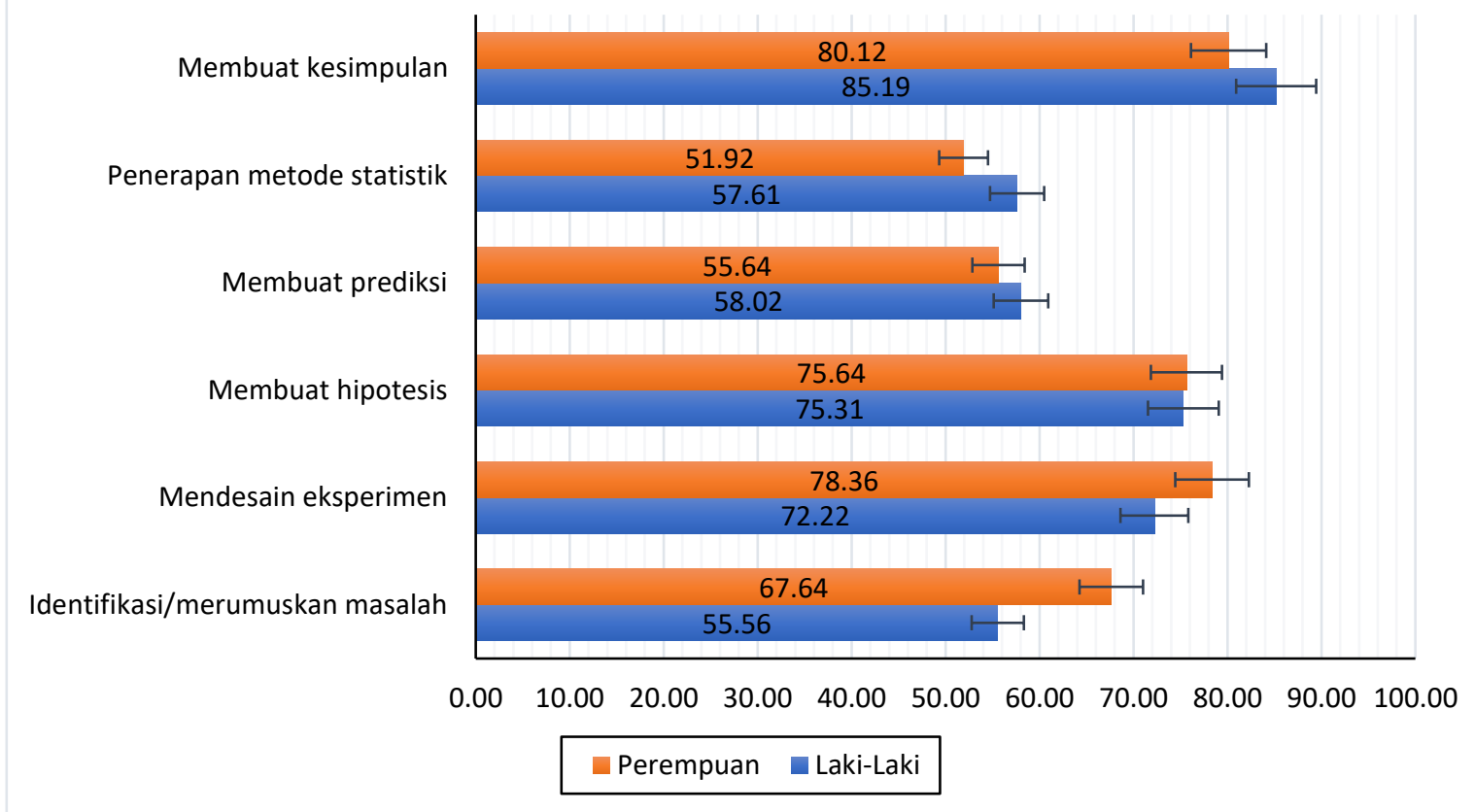

Gambar 1. Kemampuan proses inkuiri rata-rata mahasiswa calon guru IPA berdasarkan gender. Error bar sebesar 5\%

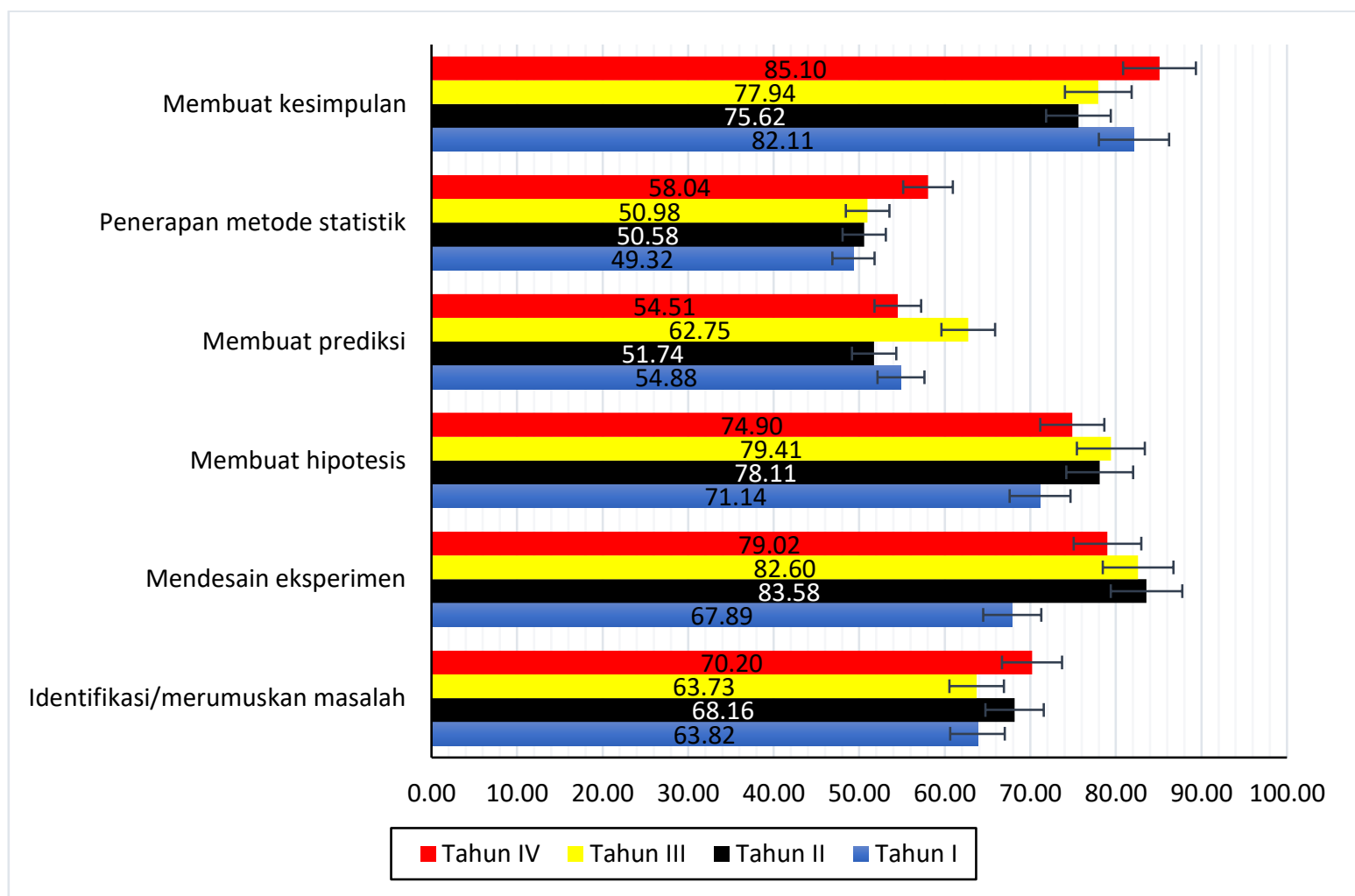

Gambar 2. Kemampuan proses inkuiri rata-rata mahasiswa calon guru IPA berdasarkan lama studi. Error bar sebesar 5\% 


\section{Kemampuan Proses Inkuiri Mahasiswa Calon Guru IPA berdasarkan Gender}

Berdasarkan Gambar 1 diperoleh kecenderungan terdapat perbedaan kemampuan proses inkuiri mahasiswa calon guru berdasarkan gender, khususnya pada indikator identifikasi/merumuskan masalah, mendesain eksperimen, membuat prediksi, penerapan metode statistik, dan membuat kesimpulan. Mahasiswa calon guru IPA laki-laki cenderung lebih unggul dalam membuat prediksi, penerapan metode statistik, dan membuat kesimpulan. Mahasiswa calon guru IPA perempuan cenderung unggul dalam identifikasi/merumuskan masalah dan mendesain eksperimen. Hal menarik lainnya adalah tidak ada perbedaan dalam hal merumuskan hipotesis baik bagi mahasiswa calon guru IPA berjenis kelamin laki-laki maupun perempuan.

Kemampuan identifikasi/merumuskan masalah dan mendesain eksperimen merupakan salah satu jenis keterampilan berpikir kreatif. Hasil riset ini menunjukkan bahwa mahasiswa calon guru IPA perempuan cenderung memiliki keterampilan berpikir kreatif yang lebih baik daripada mahasiswa calon guru IPA laki-laki. Sebaliknya, kemampuan membuat prediksi, penerapan metode statistik, dan membuat kesimpulan merupakan bagian dari keterampilan berpikir kritis. Hal ini menunjukkan bahwa mahasiswa calon guru IPA laki-laki lebih baik performanya dalam keterampilan berpikir kritis dibanding dengan mahasiswa calon guru IPA perempuan. Hal yang menarik adalah dalam kemampuan merumuskan hipotesis, mahasiswa laki-laki dan perempuan tidak menunjukkan performa yang berbeda. Padahal keterampilan hipotesis cenderung dipengaruhi oleh kedua jenis keterampilan berpikir (kreatif dan kritis). Kreatif dalam merumuskan berbagai hipotesis yang mungkin, sedangkan kritis diperlukan untuk memutuskan hipotesis yang paling mendekati dengan hasil. Hal ini juga tampak pada kemampuan membuat prediksi, yakni perbedaan performa mahasiswa laki-laki dan perempuan tidak jauh berbeda.

Hasil riset ini menunjukkan kesesuaian dengan hasil penelitian Chang, Li, Chen, \& Chiu (2015), yaitu berpikir kritis dan berpikir kreatif bisa saling berlawanan atau saling melengkapi, hasil penelitian yang relevan sebelumnya belum menyimpulkan bagaimana hubungan kedua jenis keterampilan berpikir tersebut berinteraksi. Walaupun demikian program pendidikan kualifikasi sarjana calon guru IPA di LPTK perlu untuk mengembangkan keterampilan berpikir ilmiah yang mendukung kemampuan proses inkuiri mahasiswa calon guru IPA berdasarkan gender dan kecenderungan kelebihan dan kekurangan berdasarkan performa yang diperoleh dari hasil penelitian ini.

\section{Kemampuan Proses Inkuiri Mahasiswa Calon Guru IPA berdasarkan Lama Studi}

Jika ditinjau berdasarkan lama studi, terdapat pola yang cukup unik dan tidak kontinu atas beragam indikator kemampuan proses inkuiri mahasiswa calon guru IPA. Kemampuan mengidentifikasi/merumuskan masalah bagi mahasiswa tahun IV meraih skor rata-rata tertinggi. Di sisi lain, mahasiswa tahun I dan III memeroleh skor rerata di bahwa mahasiswa tahun II. Hasil 
ini menunjukkan lama studi tidak menunjukkan kecenderungan yang linier dengan kemampuan identifikasi/merumuskan masalah.

Kemampuan mendesain eksperimen mahasiswa tahun II lebih baik, sedangkan mahasiswa tahun III memiliki skor sedikit lebih rendah dari mahasiswa tahun II, tetapi jauh lebih baik daripada mahasiswa tahun IV dan tahun I. Mahasiswa tahun I memiliki kemampuan mendesain eksperimen yang terendah. Sedangkan untuk kemampuan membuat hipotesis mahasiswa tahun III lebih unggul dibandingkan mahasiswa tahun IV, II, dan I. Hal yang menarik adalah kemampuan membuat hipotesis mahasiswa tahun II sedikit lebih baik dari mahasiswa tahun IV.

Kemampuan penerapan metode statistik menunjukkan kecenderungan atau pola yang linier dengan lama masa studi mahasiswa. Semakin lama masa studi mahasiswa, maka kemampuan penerapan metode statistik dalam mengolah data hasil eksperimen menunjukkan performa yang semakin baik. Hal ini sejalan dengan mayoritas kurikulum pendidikan calon guru IPA program sarjana di LPTK yang mulai mengenalkan metode statistik di tahun ke-3 dan aktif digunakan di tahun ke-4 khususnya dalam penyelesaian tugas akhir.

Kemampuan membuat kesimpulan menujukkan pola yang unik. Mahasiswa tahun IV menunjukkan performa paling baik yang disusul oleh mahasiswa tahun I, sedangkan mahasiswa tahun III dan II menunjukkan performa yang lebih rendah dibandingkan dengan mahasiswa tahun IV dan tahun I. Mahasiswa tahun II menunjukkan performa terendah dalam kemampuan membuat kesimpulan.

Jika ditinjau dari rerata skor tiap angkatan, maka diperoleh gambaran bahwa performa terbaik ada pada kemampuan membuat kesimpulan, sedangkan performa terendah ada pada penerapan metode statistik. Selain itu, kemampuan membuat prediksi juga rendah. Kemampuan membuat prediksi yang rendah juga ditunjukkan oleh rendahnya performa rerata mahasiswa dalam membuat hipotesis. Hal yang menarik adalah performa mahasiswa dalam mendesain eksperimen sudah menunjukkan kemampuan kedua terbaik setelah kemampuan membuat kesimpulan.

Hasil penelitian ini mirip dengan studi yang dilakukan oleh Farsakoğlu et al. (2012) yang juga menunjukkan perkembangan keterampilan yang tidak linier antara mahasiswa tahun I hingga tahun IV. Sebaliknya, kemampuan mahasiswa tahun IV secara umum lebih baik daripada mahasiswa tahun I, II, dan III dan hal ini mengindikasikan Program Pendidikan Guru IPA harus secara efektif menekankan pada penguasaan keterampilan proses (Yakar, 2014).

\section{Refleksi atas Pembelajaran Mahasiswa Calon Guru IPA di LPTK}

Hasil-hasil ini mengindikasikan pola pembelajaran bagai mahasiswa calon guru IPA di LPTK cenderung masih belum konsisten untuk menerapkan pembelajaran berbasis inkuiri. Penekanan terhadap penguasaan indikator-indikator kemampuan proses inkuiri masih belum 
mendapat perhatian dan terstruktur dalam proses pembelajaran. Hal ini menyebabkan performa kemampuan proses inkuiri mahasiswa calon guru IPA masih beragam dan cenderung tidak konsisten dengan masa studi mahasiswa calon guru tersebut di LPTK.

Para ahli sendiri masih belum menentukan apa makna tunggal dari inkuiri dikarenakan ada banyak definisi dan variasi model pembelajaran inkuiri (Bunterm et al., 2014). Hal ini tentu membuat masalah tersendiri di LPTK mengingat belum adanya konsensus yang pasti terkait inkuiri yang akan digunakan dalam proses pembelajaran. Ketidakjelasan ini jelas akan berdampak bagi mahasiswa calon guru IPA, yang pada akhirnya cenderung menemukan hal-hal yang berbeda antara yang dipelajari di LPTK dan hal-hal yang dibutuhkan ketika berkarir sebagai guru IPA di SMP/MTs. Selain itu, kurangnya kemampuan konsep substantif dan konsep prosedural guru IPA akan berpengaruh terhadap kemampuan guru dalam membelajarkan proses-proses inkuiri kepada para peserta didiknya dalam mengenal metode ilmiah sebagai bekal dasar dalam pemecahan masalah secara mandiri.

Kurangnya penekanan pada penerapan metode statistik seperti mengumpulkan data, menyajikan data, dan menganalisis data sesuai dengan metode statistik serta lemahnya penguasaan indikator-indikator kemampuan proses inkuiri lainnya juga menguatkan mengapa hasil literasi ilmiah kita masih rendah. Padahal literasi ilmiah merupakan salah satu tujuan pendidikan sains global saat ini (Forbes et al., 2020). Lingkungan belajar yang mendukung dan kondusif mutlak diperlukan dalam menunjang partisipasi aktif pembelajar dengan menekankan pada tiga aspek, yaitu konseptual, prosedural, dan personal (Adi Badiozaman, Leong, \& Jikus, 2019; Bevins \& Price, 2016). Oleh karena itu, seyogyanya LPTK harus mengevaluasi dan memperbaiki pola pembelajaran program sarjana guru IPA dengan jalan memfokuskan pada kemampuan proses inkuiri mahasiswa calon guru IPA.

\section{SIMPULAN}

Mahasiswa calon guru IPA laki-laki cenderung lebih unggul dalam membuat prediksi, penerapan metode statistik, dan membuat kesimpulan, sedangkan mahasiswa calon guru IPA perempuan cenderung unggul dalam identifikasi/merumuskan masalah dan mendesain eksperimen. Selain itu, hanya indikator kemampuan menerapkan metode statistik yang menunjukkan pola linier dengan lama masa studi mahasiswa calon guru IPA.

Riset ini juga dapat memberikan gambaran singkat mengenai pengembangan profesional mahasiswa calon guru IPA, yaitu kemampuan proses inkuiri berdasarkan gender dan lama studi. Kami juga menyadari terdapat beberapa keterbatasan metodologis. Pertama, riset ini tidak dapat mengambil subjek penelitian yang besar dan beberapa LPTK yang akan menjamin generalisasi temuannya terhadap seluruh mahasiswa calon guru IPA. Kedua, temuan dari penelitian ini belum melibatkan perspektif dari para pemangku kepentingan di LPTK dan pengguna lulusan. Selain itu, 
belum diterapkan uji statistik inferensial yang mutakhir untuk memberikan signifikansi terhadap hasil-hasil yang diperoleh.

\section{UCAPAN TERIMA KASIH}

Ucapan terima kasih ditujukan kepada para reviewer yang telah memberikan masukan dan saran untuk meningkatkan kualitas tulisan ini.

\section{REFERENSI}

Abrahams, I., \& Reiss, M. J. (2015). The assessment of practical skills. School Science Review, 96(357), 40-44.

Adi Badiozaman, I. F. binti, Leong, H., \& Jikus, O. (2019). Investigating student engagement in Malaysian higher education: A self-determination theory approach. Journal of Further and Higher Education, 1-15. https://doi.org/10.1080/0309877X.2019.1688266

Aiken, L. R. (1985). Three coefficients for analyzing the reliability and validity of ratings. Educational and Psychological Measurement, 45(1), 131-142. https://doi.org/10.1177/0013164485451012

Bancroft, S. F., \& Nyirenda, E. M. (2020). Equity-focused K-12 science teacher professional development: A review of the literature 2001-2017. Journal of Science Teacher Education, 31(2), 151-207. https://doi.org/10.1080/1046560X.2019.1685629

Bevins, S., \& Price, G. (2016). Reconceptualising inquiry in science education. International Journal of Science Education, 38(1), 17-29. https://doi.org/10.1080/09500693.2015.1124300

Bunterm, T., Lee, K., Ng Lan Kong, J., Srikoon, S., Vangpoomyai, P., Rattanavongsa, J., \& Rachahoon, G. (2014). Do different levels of inquiry lead to different learning outcomes? A comparison between guided and structured inquiry. International Journal of Science Education, 36(12), 1937-1959. https://doi.org/10.1080/09500693.2014.886347

Chang, Y., Li, B.-D., Chen, H.-C., \& Chiu, F.-C. (2015). Investigating the synergy of critical thinking and creative thinking in the course of integrated activity in Taiwan. Educational Psychology, 35(3), 341-360. https://doi.org/10.1080/01443410.2014.920079

Fadzil, H. M., \& Saat, R. M. (2014). Exploring the influencing factors in students' acquisition of manipulative skills during transition from primary to secondary school. Asia-Pacific Forum on Science Learning and Teaching, 15(2), Article 3, 1-18.

Farsakoğlu, Ö. F., Şahin, Ç., \& Karsli, F. (2012). Comparing science process skills of prospective science teachers: A cross-sectional study. Asia-Pacific Forum on Science Learning and Teaching, 13(1), Article 6, 1-21.

Forbes, C. T., Neumann, K., \& Schiepe-Tiska, A. (2020). Patterns of inquiry-based science instruction and student science achievement in PISA 2015. International Journal of Science Education, 1-24. https://doi.org/10.1080/09500693.2020.1730017

Gilbert, J. (2016). Transforming science education for the anthropocene-is it possible? Research in Science Education, 46(2), 187-201. https://doi.org/10.1007/s11165-015-9498-2

Kowalski, S. M., Taylor, J. A., Askinas, K. M., Wang, Q., Zhang, Q., Maddix, W. P., \& Tipton, E. (2020). Examining factors contributing to variation in effect size estimates of teacher outcomes from studies of science teacher professional development. Journal of Research on Educational Effectiveness, 1-29. https://doi.org/10.1080/19345747.2020.1726538

Marco-Bujosa, L. M., McNeill, K. L., \& Friedman, A. A. (2019). Becoming an urban science 
teacher: How beginning teachers negotiate contradictory school contexts. Journal of Research in Science Teaching. https://doi.org/10.1002/tea.21583

Molefe, L., \& Stears, M. (2014). Rhetoric and reality: Science teacher educators' views and practice regarding science process skills. African Journal of Research in Mathematics, Science and Technology Education, 18(3), 219-230. https://doi.org/10.1080/10288457.2014.942961

Nichol, C., Chow, A., \& Furtwengler, S. (2018). Year-long teacher professional development on fifth grade student science outcomes. International Journal of Science Education, 40(17), 20992117. https://doi.org/10.1080/09500693.2018.1521027

Nieveen, N., \& Folmer, E. (2013). Formative evaluation in educational design research. In T. Plomp \& N. Nieveen (Eds.), Educational Design Research - Part A: An Introduction (pp. 152-169). Enschede: Netherlands Institute for Curriculum Development.

Rodriguez, A. J. (2015). Managing institutional and sociocultural challenges through sociotransformative constructivism: A longitudinal case study of a high school science teacher. Journal of Research in Science Teaching, 52(4), 448-460. https://doi.org/10.1002/tea.21207

Wright, K. B. (2019). Improvement science as a promising alternative to barriers in improving STEM teacher quality through professional development. The Clearing House: A Journal of Educational Strategies, Issues and Ideas, 92(1-2), 1-8. https://doi.org/10.1080/00098655.2018.1532953

Yakar, Z. (2014). Effect of teacher education program on science process skills of pre-service science teachers. Educational Research and Reviews, 9(1), 17-23. https://doi.org/10.5897/ERR2013.1530

Zeyer, A. (2018). Gender, complexity, and science for all: Systemizing and its impact on motivation to learn science for different science subjects. Journal of Research in Science Teaching, 55(2), 147-171. https://doi.org/10.1002/tea.21413 